\title{
Genetic analysis of Canine adenovirus type 2 strains circulating in Turkey from past to present
}

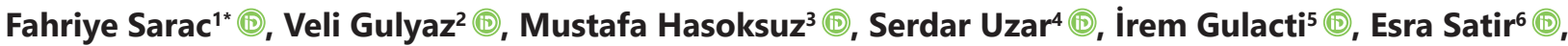 \\ Pelin Tuncer-Göktuna7 (i), Eray Atil ${ }^{8}$ (i) \\ 1,4,5,6,7,8 Pendik Veterinary Control Institute, Pendik, Istanbul, Turkey. \\ ${ }^{2}$ Harran University, Faculty of Veterinary Medicine, Department of Virology, Şanlıurfa, Turkey. \\ ${ }^{3}$ Istanbul University-Cerrahpasa, Faculty of Veterinary Medicine, Department of Virology, Hadimkoy, Istanbul, Turkey.
}

Geliş Tarihi / Received: 05.10.2021, Kabul Tarihi / Accepted: 02.12.2021

\begin{abstract}
Canine Adenovirus Type-1 (CAV-1) and Canine Adenovirus Type-2 (CAV-2) are causes of infectious canine hepatitis and infectious canine laryngotracheitis in both domestic and wild life, respectively. The epidemiology of the virus is not clear enough in the most territory. For this purpose, strains circulating in Turkey over a ten-year period were examined at the molecular level and a genetic heterogeneity was observed. In order to carry out this study, 32 fecal samples collected from shelter dogs with diarrhea in 2011 were used. Firstly, virus isolation was performed in MDCK cell line and cytopathogenic effects were observed in 4/32 samples. Secondly, four CPE-positive isolates were found positive for the E3 gene of CAV-2 by PCR. Strains obtained as a result of sequencing were placed on a different branch from other Turkish isolates under the same subgroup in the phylogenetic tree. According to partial E3 gene analysis, seven amino acid substitutions were detected between the strains. Due to Shannon entropy value and ConSurf analysis, it was determined that all amino acid changes occurred in important antigenic regions. This study pointed out the possible genetic heterogeneity among Turkish CAV-2 strains.
\end{abstract}

Keywords: Canine adenovirus type 2, molecular characterization, virus isolation

\section{Geçmişten günümüze Türkiye'de sirküle olan Canine adenovirus tip 2 suşlarının genetik incelemesi}

\begin{abstract}
Özet: Canine Adenovirus Tip-1 (CAV-1) ve Canine Adenovirus Tip-2 (CAV-2) hem evcil hem de vahşi yaşamda sırasıyla enfeksiyöz köpek hepatiti ve enfeksiyöz köpek laringotrakeitinin nedenleridir. Virus epidemiyolojisi çoğu bölgede yeterince net değildir. Bu amaçla Türkiye'de on yıllık bir süre zarfında sirküle olan suşlar moleküler düzeyde incelendi ve genetik bir heterojenlik gözlemlendi. Bu çalışmanın gerçekleştirilebilmesi için 2011 yılında ishalli barınak köpeklerinden toplanan 32 dışkı örneği kullanıldı. İlk olarak, MDCK hücre hattında virus izolasyonu yapıldı ve 4/32 örnekte sitopatojenik etkiler (CPE) gözlendi. İkinci olarak, CPE pozitif dört izolat CAV-2'nin E3 geni yönünden PCR ile pozitif bulundu. Sekans işlemi sonucu elde edilen diziler filogenetik ağaçta aynı alt grup altındaki diğer Türk izolatlarından farklı bir dal üzerine yerleşti. Kısmi E3 gen analizine göre, suşlar arasında yedi amino asitte değişim tespit edildi. Shannon entropi değeri ve ConSurf analizine göre tüm amino asit değişikliklerinin önemli antijenik bölgelerde meydana geldiği belirlendi. Bu çalışma, Türkiye CAV-2 suşları arasındaki olası genetik heterojeniteye dikkat çekmektedir.
\end{abstract}

Anahtar kelimeler: Canine adenovirus tip 2, moleküler karakterizasyon, virus izolasyonu

\section{Introduction}

Adenoviruses are enveloped, fully hexo-square, with icosahedral symmetry and $70-90 \mathrm{~nm}$ in diameter. The viral genome is a double-stranded single linear DNA molecule size of $26-45 \mathrm{kbp}$, and the viral genome synthesizes about 40 proteins (Barthold et al. 2011). Mapping with restriction endonucleases and sequencing of genomic DNA has been useful for the precise categorization of viral strains. In general, these results are consistent with the categorization results based on serological crossreactions (Parthiban et al. 2009).

Canine adenovirus type- 1 (CAV- 1 ) causes infectious canine hepatitis $(\mathrm{ICH})$ by replicating in the digestive tract and vascular endothelium. Clinical signs of CAV-1 infection include fever, apathy, anorexia, increased thirst, and abdominal pain on 
palpation behind the liver that appears swollen. Most CAV-1 infections in dogs are subclinical, in some cases, the virus causes systemic disease (Mohammadi et al. 2011). Canine adenovirus type2 (CAV-2) mostly infects respiratory tissues and induces canine infectious laryngotracheitis in dogs, raccoons, foxes, wolves, and marine mammals (Hamir et al. 1992; Hu et al. 2001; Parthiban et al. 2009; Yang et al. 2020). It causes a localized respiratory disease in dogs and is one of the potential causes of the canine infectious respiratory disease complex (CIRDC) or kennel cough syndrome (an acute respiratory disease of canines). It is characterized by sudden onset, cough with variable expectoration, and nasovascular discharge (Chaturvedi et al. 2008; Day et al. 2020). These signs may vary according to the host immune status and virus strain. Puppies are the most susceptible group to this infection and present the highest fatality rate (Cunha et al. 2020). Even the main route of spread of CAV-2 is the respiratory tract, both viruses are also shed in the feces and urine of the infected or recovered dogs (Hu et al. 2001; Mohammadi et al. 2011), thus urine and feces are important sources of infection to healthy dogs (Chaturvedi et al. 2008). Although there are antigenic relationships and cross-protective immunity between these two viruses, restriction endonuclease analysis has shown that they are genetically different types. The nucleotide similarity between the two viruses has been reported to be $75 \%$ (Buonavoglia and Martella 2007). The killed or attenuated CAV-2 vaccine can be used to protect dogs from both infections and does not cause postvaccinal corneal edema unlike the CAV-1 vaccine (Hu et al. 2001).

Vaccines have been widely used for many years. It has been stated that $\mathrm{ICH}$ has disappeared with herd immunity obtained in areas where vaccination has been done for years (Barthold et al. 2011). In Turkey, a programmed vaccination against adenoviral infections is not carried out only imported vaccines are applied upon request of animal owners in private clinics.

The presence of adenovirus infections has been demonstrated mostly by serological methods and some strains have been sequenced (Yıldırım et al. 2009; Gür and Acar 2009; Bulut et al. 2013; Can Şahna and Aslan 2015; Timurkan et al. 2018). However, detailed molecular studies have not been conducted in Turkey. For this purpose, to investigate the genetic diversity among canine adenovirus strains in Turkey, sequences obtained from the west of the country were compared with other CAV-2 strains detected from eastern Turkey and the world.

\section{Material and methods}

\section{Clinical samples}

A total of 32 fecal samples collected from 0-6 months old unvaccinated dogs with diarrhea were sent to Pendik Veterinary Control Institute (PVCI) in 2011 for the diagnosis from three shelters in Istanbul province of western Turkey. Samples were dispersed and homogenized in $2 \mathrm{ml}$ of sterile PBS treated with antibiotics (penicillin $5000 \mathrm{IU} / \mathrm{ml}$, streptomycin 2500 $\mu \mathrm{g} / \mathrm{ml}$ ) and centrifuged at $3000 \mathrm{rpm}$ for 30 minutes. Supernatants were filtered by $0.22 \mu \mathrm{l}$ and kept at $-80^{\circ} \mathrm{C}$ until use. As these samples were sent to the $\mathrm{PVCl}$ for diagnosis, no ethical approval was required.

\section{Virus isolation and titer determination}

For the virus isolation, blind passages were performed immediately after the samples reached the laboratory. The $100 \mu \mathrm{l}$ supernatants of the samples were inoculated into Madin Darby canine kidney (MDCK) cell cultures $\left(2 \times 10^{5} / \mathrm{ml}\right.$ cells in 25 $\mathrm{cm}^{2}$ flasks) then incubated for 1 hour at $37^{\circ} \mathrm{C}$ for adsorption of the virus. The surface of the cells was washed with PBS and the cell cultures were incubated at $37^{\circ} \mathrm{C}$ by adding E-MEM (Multicell, Canada) containing 2\% FCS (GE Healthcare, Sweden). At the end of the $7^{\text {th }}$ day or when $80-90 \%$ cytopathic effect (CPE) was observed in cells (within 3-4 days), flasks were placed in the freezer at $-20^{\circ} \mathrm{C}$. Suspensions were freeze-thawed in a $37^{\circ} \mathrm{C}$ water bath and then centrifuged at $3000 \mathrm{rpm}$ for 30 minutes at $4^{\circ} \mathrm{C}$ and collected for the following passages and molecular analysis.

Serial dilutions were performed from $10^{-1}$ to $10^{-6}$ in 96 well plates to determine the $\mathrm{TCID}_{50} / \mathrm{ml}$ titers of CAV strains isolated in MDCK cell cultures. From each dilution, $100 \mu \mathrm{l}$ was placed in four wells, and $50 \mu \mathrm{l}$ of the MDCK cell culture $\left(3 \times 10^{5} / \mathrm{ml}\right.$ cells $)$ was added to all dilutions. Wells were also prepared for cell control. The plate was incubated at $37^{\circ} \mathrm{C}$ with $5 \% \mathrm{CO}_{2}$ and checked every day. At the end of four days, the formation of CPE due to the growth of viruses was assessed. The $T C I D_{50}$ was calculated by Spearman- Kärber method (Spearman 1908; Kärber 1931).

\section{Molecular analysis}

After the third blind passage, CPE positive cell culture supernatants were analyzed by PCR assay. 
As a positive control, attenuated Vanguard Plus 5L4' CAV-2 vaccine strain (Pfizer Animal Health, Lincoln, Nebraska, $A B D$ ) and for DNA extraction DNeasy Blood \& Tissue Kit (QIAGEN Group, US) were used according to the protocols specified in the kit. To amplification of E3 gene, HA1; forward 5-'CGC GCT GAA CAT TAC TAC CTT GTC-3' and HA2; reverse 5'CCT AGA GCA CTT CGT GTC CGC TT-3' primers were preferred in this study. HA1 is complementary to the genomic L chain at positions 770 to 791 in CAV-1 and 1387 to 1408 in CAV-2. HA2 is complementary to the genomic $R$ chain at positions 1274 to 1253 in CAV-1 and 2413 to 2392 in CAV-2 (Yang et al. 2020). The PCR was optimized in $25 \mu \mathrm{l}$ reaction volume. The reaction mixture consisted of $1 \times P C R$ buffer, $1.5 \mathrm{mM}$ $\mathrm{MgCl}, 0.2 \mathrm{mM}$ of each deoxynucleotide, $15 \mathrm{pmol}$ of each primer, $0.5 \mathrm{U}$ of Taq DNA polymerase (MBI, Fermentas), and $5 \mu$ l of template DNA (50 ng). PCR was conducted in a thermal cycler (Techne, UK) for $9 \mathrm{~min}$ at $95^{\circ} \mathrm{C}$ and $35 \mathrm{cycles}$ at $94^{\circ} \mathrm{C}$ for $1 \mathrm{~min}, 59^{\circ} \mathrm{C}$ for $1 \mathrm{~min}, 72^{\circ} \mathrm{C}$ for $1 \mathrm{~min}$, and a final amplification at $72^{\circ} \mathrm{C}$ for $10 \mathrm{~min}$. PCR products (508 bp for CAV1 and $1030 \mathrm{bp}$ for (AV-2) were visualized under ultraviolet light after electrophoresis on $1 \%$ agarose gel, stained with ethidium bromide.

Following the $P C R$, the products were purified using PCR Purification Kit (Min Elute ${ }^{\circledR}$, QIAGEN, USA), and the purified PCR products were subjected to an automatic sequencer (ABI $3130 \mathrm{XL}$, USA) available in the Molecular Genetic Laboratory Department of $\mathrm{PVCl}$. Four sequences have been loaded to the GenBank under accession numbers in 2021: MW811327- MW811330. Those and other reference DNA sequences obtained from the
NCBI GenBank were analyzed in the MEGA 7.0.26 software. The Clustal W alignment method was used to determine the differences in amino acids. For phylogenetic relationships, the neighbor-joining method was used with 1500 bootstrap replicates. Other sequences GenBank accession numbers used in the phylogenetic tree were: EF057101, GQ340423, GQ915311， GU226970， JN418926， JX416838, JX416841， JX416842， KF676978， KU315335, KU725674, KY775390, KY775391, KY775392, KY775393, M60937, MN652567, MT318141, MT892837, S38212, S38238, U77082, Y07760.

Predicting the antigenic significance of variable residues and estimating the epitopes in the E3 gene, Shannon entropy (Threshold was set as default: 1) (http://imed.med.ucm.es/PVS/), and conservation surface mapping (ConSurf) were used, respectively (Shannon 1948; Ashkenazy et al. 2010, 2016; Celniker et al. 2013).

\section{Results}

\section{Virus isolation and titers}

After inoculation of specimens onto MDCK cells, rounding of cells, detachment from the surface, and the typical grape cluster-like CPE were observed in MDCK cells only in 4/32 samples after $2^{\text {nd }}-3^{\text {rd }}$ passage onwards (Figure 1). The titer of the strains in the MDCK cells at 96 hours post-infection was found to be as $10^{-6.0}, 10^{-6.0}, 10^{-6.5}, 10^{-6.75} \mathrm{TCID}_{50} / \mathrm{ml}$, and isolates were named as CAV2/TUR/PenCAV-5/2011, CAV2/ TUR/PenCAV-6/2011, CAV2/TUR/PenCAV-7/2011, and CAV2/TUR/PenCAV-9/2011, respectively.

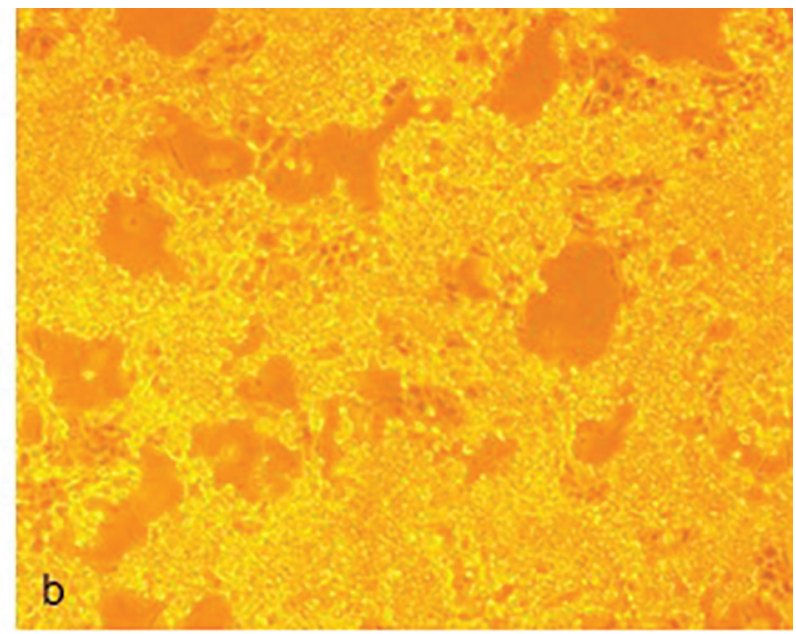

Figure 1. CPE view of CAV isolates in MDCK cell cultures*.

*a: negative control, b: vacuole and rounding of cells between cells 


\section{Molecular analysis}

The supernatant of four isolates and positive control were found positive by PCR of the E3 gene with amplification of expected $1030 \mathrm{bp}$ fragment in agarose gel electrophoresis that indicates isolates belong to CAV-2 (Figure 2).

Phylogenetic comparison of E3 gene nucleotides of canine adenovirus isolates and reference viruses from GeneBank are shown in Figure 3. According to the reference gene (Acces. No: GQ915311), the amino acid (aa) substitutions in our four isolates were detected at positions: $17 \mathrm{H}-\mathrm{P}$, $126 \mathrm{~A}-\mathrm{T}, 178 \mathrm{D}-\mathrm{N}$, and $184 \mathrm{I}-\mathrm{T}$. The aa substitutions between Turkey strains were shown in the grey boxes, while the aa differences between Turkey and America-Europe strains which also include one of the CAV-2 vaccine strains were displayed in empty boxes in Figure 4. Due to Shannon entropy value the residues $15,17,52,63,70,93,97,109,119,126$, $138,142,147,152,172,178,184,186,201,216,221$, $222,243,250,251$, and 254 on E3 gene had a score bigger than 1 . The lowest and the highest ConSurf antigenicity scores of the 23 aa positions, excluding residues 93,147 , and 243 , were detected at 4.579 and 7.515 , respectively.

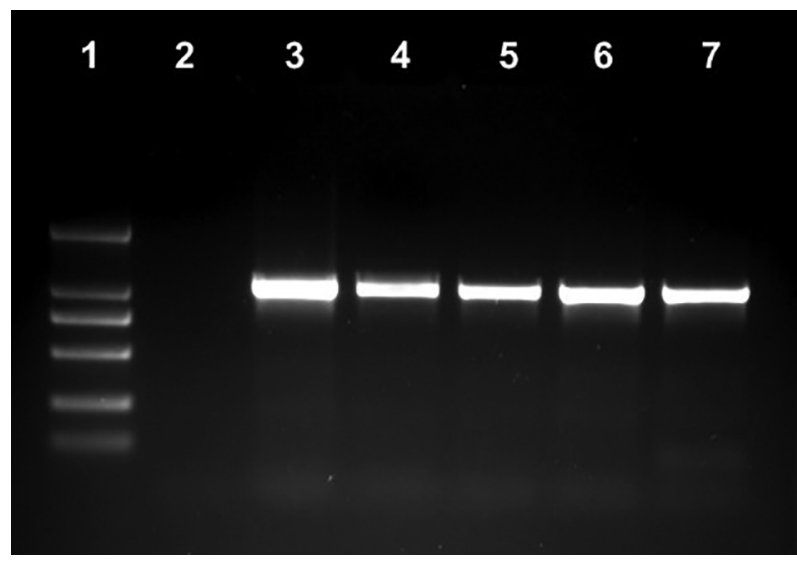

Figure 2. PCR product of amplified E3 gene of canine adenovirus*

*1: DNA ladder (100-2000 bp, Qiagen, cat no. 239135), 2: Negative control, 3: Positive control, 4: CAV2/TUR/PenCAV-5/2011, 5: CAV2/TUR/PenCAV-6/2011，6: CAV2/TUR/PenCAV-7/2011， 7: CAV2/TUR/PenCAV-9/2011

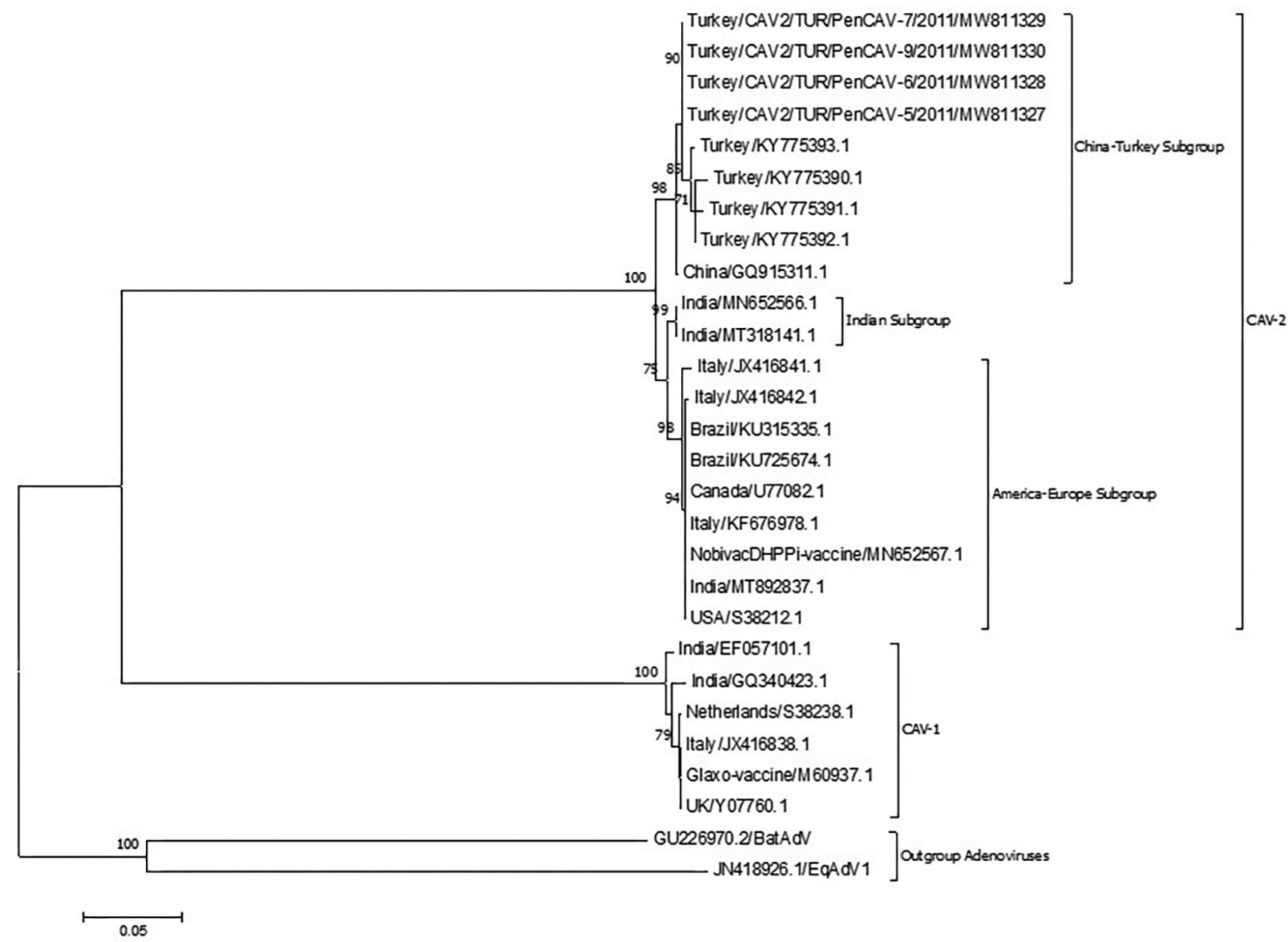

Figure 3. Phylogenetic tree of E3 gene of canine adenovirus isolates and reference viruses. 


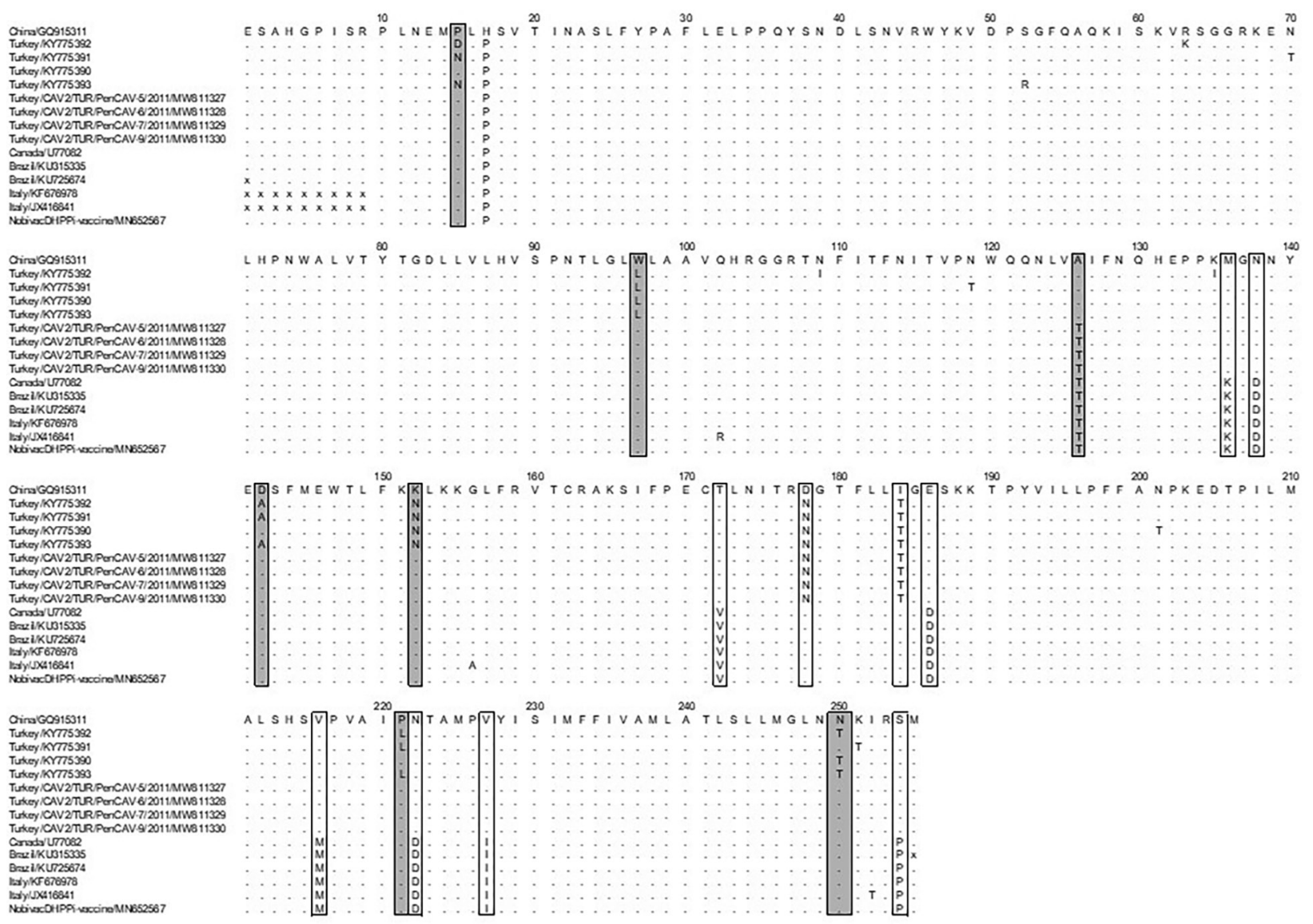

Figure 4. The amino acid comparison of CAV-2 strains among partial-length E3 gene (255 amino acids)*. *The gray boxes indicate the aa substitutions between Turkey strains, while empty boxes indicate the aa substitutions between Turkey and America-Europe strains.

\section{Discussion and Conclusion}

$\mathrm{ICH}$ is caused by CAV- 1 by replicating in the digestive tract and vascular endothelium, while CIRDC is a disease complex that occurs in dogs usually housed in groups, for example, in rehoming centers, boarding kennels, or veterinary hospitals. Both CAV1 and -2 have been recovered from dogs suffering from CIRDC, but CAV-2 has been more commonly associated with the disease (Erles et al. 2004). There have been indications that CAV-2 may also be an enteric pathogen (Hamelin et al. 1985; Macartney et al. 1988; Hu et al. 2001). Moreover, it was presented that it can cross the blood-brain barrier (Benetka et al. 2006).

Antigenically related but genetically different two canine adenoviruses are important infectious viruses not only in domestic dogs but also in foxes in wildlife. However, the molecular epidemiology of the virus is not clear enough. The nucleic acid was detected in $58.8 \%$ of 51 dogs in Italy (Balboni et al. 2014). In Mexico, the antigen was shown immunohistochemically with a rate of 57\% (Damián et al. 2005). The seropositivity rates were $2.9 \%$ and $19.9 \%$ in Japan and Korea, respectively (Kim et al. 2006; Mochizuki et al. 2008). In Turkey, the seropositivity rate was reported between $36.3 \%$ and 100\% (Gür and Acar 2009; Yıldırım et al. 2009; Bulut et al. 2013; Can Şahna and Aslan 2015) and antigen detection rate was $2.5 \%$ and $8.3 \%$ in clinically ill and healthy dogs, respectively (Can Şahna and Aslan 2015; Timurkan et al. 2018).

In this study, virus isolation was performed in 4/32 (12.5\%) of fecal samples of dogs showing signs of diarrhea. The positivity rate obtained by other studies using fecal, pneumonic lung, and nasal-oropharynx swab samples were $9.17 \%$, $2.9 \%, 16 \%$, and $12.7 \%$, respectively (Mochizuki et al. 2008; Posuwan et al. 2010; Yoon et al. 2010). In addition, it was observed that CAV-2 isolation and identification data, the reproduction time, and the CPE feature of the MDCK cell culture were similar to other researchers' results (Ditchfield et al. 1962; 
Chaturvedi et al. 2008). Besides, the titers of CAV-2 were found $10^{-6.0}, 10^{-6,5}$ and $10^{-6.75} \mathrm{TCID}_{50} / \mathrm{ml}$, which were among the titers obtained $\left(10^{-4.0}-10^{-7.5} \mathrm{TCID}_{50} /\right.$ $\mathrm{ml}$ ) in other studies (Hu et al. 2001; Chaturvedi et al. 2008; Yang et al. 2020).

For diagnosing and differentiating CAV-1 and CAV-2, primers specific to the E3 region were used. For this purpose, four strains isolated in MDCK were tested in PCR and obtained positive in terms of CAV-2 nucleic acid. Parthiban et al. (2009) were gathered CAV-1 PCR amplicon from fecal samples of dogs however only CAV-2 was detected in this study. After all, it is known that the prevalence of CAV-2 in dogs is higher than CAV-1 (Balboni et al. 2014).

Timurkan et al. (2018) detected 2.5\% CAV-2 nucleic acid by PCR from nasal swab samples collected from the eastern part of Turkey. As a result of DNA partial sequence analysis, it has been reported that the nine aa differences were obtained between Turkey and America-Europe strains. On the other hand, they were found to be very similar to China strain. Therefore, they were located in the same branch in the phylogenetic tree. For 10 positions, the same aa substitutions were observed in all Turkey strains in contrast to the America-Europe strains (empty boxes in Figure 4). Unlike Timurkan et al. (2018), seven aa substitutions of MW811327MW811330 strains were seemed to be the same as America-Europe strains (grey boxes in Figure 4). Both Shannon entropy values and ConSurf scores were determined as high in the aa substitution positions of 15, 97, 126, 142, 152, 221, and 250 in Turkey strains. This may be the reason of Turkey branch is divided into two (Figure 3). The strains were grouped not only according to their location (eastern and western Turkey) but also due to body systems (respiratory and gastro-intestinal) in which they were sampled. Two different studies conducted in India pointed out some mutations have occurred in the genome. One of them detected insertion of a residue in the Indian CAV-2 strain that caused a frameshift, and the other one reported nine predominant mutations (Chander et al. 2021; Raja et al. 2021). Besides, in one study performed in red foxes in Italy, two genetically different CAV-2 strains were gathered from the same fox (in phylogenetic tree accession no: JX416841, JX416842) revealed the circulation of the different viral strains among the fox population (Balboni et al. 2013). Accordingly, it could conclude that the genetically different CAV-2 strains circulated in dog populations in Turkey for the last ten years.
While struggling with canine adenovirus infections vaccines have been widely used for many years. After the CAV-1 vaccination corneal edema could be seen. Therefore, the CAV-2 vaccine is preferred for cross-protection and has the advantage that it does not cause side effects like CAV-1. The positive effect of the vaccine has been described elsewhere (Abdelmagid et al. 2004; Barthold et al. 2011; Andrukonis et al. 2021). In Turkey, a programmed vaccination against adenoviral infections is not carried out and imported vaccines are made at the request of animal owners in private clinics. It is shown that one of the vaccine strains and the local CAV-2 isolates are located in different subgroups. It is well known that E3 protein plays an essential role in eliciting immunity by directly associated with class I major histocompatibility complex, tumor necrosis factor, and T-cell response (Kvist et al. 1978; Gooding et al. 1991; Zhang et al. 1991). Amino acid substitutions seen in the E3 gene region in strains raise the question of whether vaccine strains should be updated. However, genetic differences must be shown antigenically. According to our results, it is necessary to examine the protection of the vaccines used in Turkey with the local strains.

In conclusion, this study pointed out the possible genetic heterogeneity among CAV-2 in Turkey. This situation should be revealed clearly by examination of more samples from a wider area. In addition, investigating hexon and fiber genes will help to obtain more valuable data.

Acknowledgment: Authors thank to Ministry of Agriculture and Forestry General Directorate of Food and Control.

Ethical Statement: As these samples were sent to the PVCl in 2011 for the purpose of diagnosis, no ethical approval was required.

Conflict of Interest: The authors have no conflicts of interest to declare.

\section{References}

Abdelmagid OY, Larson L, Payne L, Tubbs A, Wasmoen T, Schultz RR. (2004) Evaluation of the efficacy and duration of immunity of a canine combination vaccine against virulent parvovirus, infectious canine hepatitis virus, and distemper virus experimental challenges. Vet Ther. 5, 173-186.

Andrukonis A, Brown KM, Hall NJ, Protopopova A. (2021) Intake vaccinations reduced signs of canine respiratory disease during an outbreak at an animal shelter. Front Vet Sci. 8, 627580. https://doi. org/10.3389/fvets.2021.627580

Ashkenazy H, Erez E, Martz E, Pupko T, Ben-Tal N. (2010) ConSurf 2010: Calculating evolutionary conservation in sequence and structure of proteins and nucleic acids. Nucleic Acids Res. 38 (Web Server issue): W529-W533. https://doi.org/10.1093/nar/gkq399

Ashkenazy H, Abadi S, Martz E, Chay O, Mayrose I, Pupko T, Ben-Tal N. (2016) ConSurf 2016: An improved methodology to estimate and 
visualize evolutionary conservation in macromolecules. Nucleic Acids Res. 44 (W1): W344-W350. https://doi.org/10.1093/nar/ gkw408

Balboni A, Verin R, Morandi F, Poli A, Prosperi S, Battilani M. (2013) Molecular epidemiology of canine adenovirus type 1 and type 2 in free-ranging red foxes (Vulpes vulpes) in Italy. Vet Mic. 162, 551-557. https://doi.org/10.1016/j.vetmic.2012.11.015

Balboni A, Mollace C, Giunti M, Dondi F, Prosperi S, Battilani M. (2014) Investigation of presence of canine adenovirus (CAV) in owned dogs in Northern Italy. Res Vet Sci. 97, 631-636. https://doi.org/10.1016/j. rvsc.2014.10.010

Barthold SW, Lairmore MD, Bowen RA, Parrish CR, Hedrick RP, Saif LJ, Knowles DP, Swayne DE. (2011) Adenoviridae. Maclachlan NJ, Dubovi EJ. eds. Fenner's Veterinary Virology. Fourth edition. Academic Press, United States, p. 203-212.

Benetka V, Weissenbock H, Kudielka I, Pallan C, Rothmuller G, Mostl K. (2006) Canine adenovirus type 2 infection in four puppies with neurological signs. Vet Rec. 158, 91-94. https://doi.org/10.1136/ vr.158.3.91

Bulut O, Yapici O, Avci O, Simsek A, Atli K, Dik I, Yavru S, Hasırcıoglu S, Kale M, Mamak N. (2013) The serological and virological investigation of canine adenovirus infection on the dogs. Scientific World Journal. 587024. https://doi.org/10.1155/2013/587024

Buonavoglia C, Martella V. (2007) Canine respiratory viruses. Veterinary Research. 38, 355-373. https://doi.org/ 10.1051/vetres:2006058

Can Şahna K, Aslan Ö. (2015) Köpek idrar ve plazma örneklerinde canine adenovirus (CAV) antijeninin ELISA ile araştırılması. Harran Univ Vet Fak Dergisi. 4, 45-47 (in Turkish with an abstract in English)

Celniker G, Nimrod G, Ashkenazy H, Glaser F, Martz E, Mayrose I, Pupko T, Ben-Tal N. (2013) ConSurf: Using evolutionary data to raise testable hypotheses about protein function. Isr J Chem. 53, 199-206. https:// doi.org/10.1002/ijch.201200096

Chander, V., Sharma, G.K., Bhatt, M, Nandi S, Mahajan S, Singh $M$, Mahendran K, Karikalan M, Pawde AM, Gupta V, Singh KP, Rajak KK, Gupta VK, Singh RK. (2021) Isolation and genetic characterization of canine adenovirus type 2 from a domestic dog showing neurological symptoms. Braz J Microbiol. https://doi.org/10.1007/ s42770-021-00540-0

Chaturvedi U, Tiwari AK, Ratta B, Ravindra PV, Rajawat YS, Palia SK, Rai A (2008) Detection of canine adenoviral infections in urine and faeces by the polymerase chain reaction. J Virol Methods. 149, 260-263. https://doi.org/10.1016/j.jviromet.2008.01.024

Cunha RDS, Silva Junior $C L$, Costa $C A$, de Aguiar HM, Junqueira Júnior DG. (2020) Comparison of immunity against canine distemper, adenovirus and parvovirus after vaccination with two multivalent canine vaccines. Vet Med Sci. 6, 330-334. https://doi.org/10.1002/ vms3.274

Damián M, Morales E, Salas G, Trigo FJ. (2005) Immunohistochemical detection of antigens of distemper, adenovirus and parainfluenza viruses in domestic dogs with pneumonia. J Comp Pathol. 133, 28993. https://doi.org/10.1016/j.jcpa.2005.05.005

Day MJ, Carey S, Clercx C, Kohnx B, Marsillo F, Thiry E, Freyburger L, Schulz B, Walker DJ. (2020) Aetiology of canine infectious respiratory disease complex and prevalence of its pathogens in Europe. J Comp Pathol. 176, 86-108. https://doi.org/10.1016/j.jcpa.2020.02.005

Ditchfield J, Macpherson LW, Zbitnew A. (1962) Association of a canine adenovirus (Toronto A 26/61) with an outbreak of laryngotracheitis ("Kennel Cough"): A preliminary report. Can Vet J. 3, 238-247.

Erles K, Dubovi EJ, Brooks HV, Brownli J. (2004) Longitudinal study of viruses associated with canine infectious respiratory disease. J Clin Microbiol. 42, 4524-4529. https://doi.org/10.1128/JCM.42.10.45244529.2004

Gooding LR, Ranheim TS, Tollefson AE, Aquino L, Duerksen-Hughes P, Horton TM, Wold WMS. (1991) The 10,400 and 14,500 dalton proteins encoded by region E3 of adenoviruses function together to protect many but not all cell lines against lysis by tumor necrosis factor. J Virol. 65, 4114-4123. https://doi.org/10.1128/JVI.65.8.41144123.1991

Gür S, Acar A. (2009) A retrospective investigation of canine adenovirus (CAV) infection in adult dogs in Turkey. J S Afr Vet Assoc. 80, 84-86. https://doi.org/10.4102/jsava.v80i2.176
Hamelin C, Jouvenne P, Assaf R. (1985) Association of a type-2 canine adenovirus with an outbreak of diarrhoeal disease among a large dog congregation. J Diarrhoeal Dis Res. 3, 84-87.

Hamir AN, Raju N, Rupprecht CE. (1992) Experimental oral administration of canine adenovirus (type 2) to raccoons (Procyon lotori). Vet Pathol. 29, 509-513. https://doi.org/10.1177/030098589202900604

Hu RL, Huang G, Qiu W, Zhong ZH, Xia XZ, Yin Z. (2001) Detection and differentiation of CAV-1 and CAV-2 by polymerase chain reaction. Vet Res Commun. 25, 77-84. https://doi.org/10.1023/a:1006417203856

Kärber G. (1931) Beitrag zur kollektiven Behandlung pharmakologischer Reihenversuche. Archiv f Experiment Pathol U Pharmakol. 162, 480483. https://doi.org/10.1007/BF01863914

Kim SH, Huh JH, Bae SY, Kim JS, Yoon SY, Lim CS, Cho Y, Kim YK, Lee KN, Lee CK. (2006) Epidemiology of respiratory viral infection in 20042006. The Korean J Lab Med. 26, 351-357. https://doi.org/10.3343/ kjlm.2006.26.5.351

Kvist S, Ostberg L, Persson H, Philipson L, Peterson PA. (1978) Molecular association between transplantation antigens and cell surface antigens in adenovirus-transformed cell line. Proc Natl Acad Sci U S A. 75, 5674-5678. https://doi.org/10.1073/pnas.75.11.5674

Macartney L, Cavanagh HM, Spibey N. (1988) Isolation of canine adenovirus-2 from the faeces of dogs with enteric disease and its unambiguous typing by restriction endonuclease mapping. Res Vet Sci. 44, 9-14.

Mochizuki M, Yachi A, Ohshima T, Ohuchi A, Ishida T. (2008) Etiologic study of upper respiratory infections of household dogs. J Vet Med Sci. 70, 563-569. https://doi.org/10.1292/jvms.70.563

Mohammadi A, Masoudian M, Nemati Y. (2011) Evaluation of PCR techniques for detection and differentiation of canine adenoviruses in faecal samples in Shiraz, Iran. Iran Bulg J Vet Med. 14, 247-251.

Parthiban M, Kumanan K, Sunder K, Senthil Kumar S, Kathiresan D. (2009) Molecular detection of canine adenovirus using polymerase chain reaction and sequencing. TNJVAS. 5, 140-142.

Posuwan N, Payungporn S, Thontiravong A, Kitikoon P, Amonsin A, Poovorawan Y. (2010) Prevalence of respiratory viruses isolated from dogs in Thailand during 2008-2009. Asian Biomed. 4, 563-569. https://doi.org/10.2478/abm-2010-0071

Raja P, Sachin V, Parthiban M, Janaki PA. (2021). Molecular characterization of canine adenovirus type 2 in dogs from India. Virus Dis. 32, 369374. https://doi.org/10.1007/s13337-021-00690-7

Shannon CE. (1948) The mathematical theory of communication. Bell Syst Tech J. 27, 379-423 \& and 623-656. https://doi. org/10.1002/j.1538-7305.1948.tb01338.x

Spearman C. (1908) The method of "right and wrong cases" (constant stimuli) without Gauss's formula. Br J Psychol. 2, 227-242. https:// doi.org/10.1111/j.2044-8295.1908.tb00176.x

Timurkan MO, Aydin H, Alkan F. (2018) Detection and molecular characterization of canine adenovirus type-2 (CAV-2) in dogs with respiratory tract symptoms in shelters in Turkey. Veterinarski Arhiv. 88, 467-479. https://doi.org/doi: 10.24099/vet.arhiv.0052

Universidad Complutense de Madrid, Protein Variability Server [(online]). Access address: Website http://imed.med.ucm.es/PVS/ Date of access: Accessed 18 April 2021.

Yang DK, Kim HH, Yoo JY, Ji M, Han BH, Oh S, Hyun BH. (2020) Immunogenicity of a new, inactivated canine adenovirus Type2 vaccine for dogs. Clin Exp Vaccine Res. 9, 40-47. https://doi. org/10.7774/cevr.2020.9.1.40

Yıldırım Y, Kırmızıgül AH, Gökçe E. (2009) Seroprevalence of canine adenovirus (CAV) infection in Kars dogs in Turkey. YYU Vet Fak Derg. 20, 37-39.

Yoon SS, Byun JW, Park YI, Kim MJ, Bae YC, Song JY. (2010) Comparison of the diagnostic methods on the canine adenovirus type-2 infection. Basic Appl Pathol. 3, 52-56. https://doi.org/10.1111/j.17559294.2010.01073.x

Zhang XL, Bellett AJ, Hla RT, Braithwaite AW, Müllbacher A. (1991) Adenovirus type $5 \mathrm{E} 3$ gene products interfere with the expression of the cytolytic T cell immunodominant E1a antigen. Virology. 180, 199-206. https://doi.org/10.1016/0042-6822(91)90024-6 